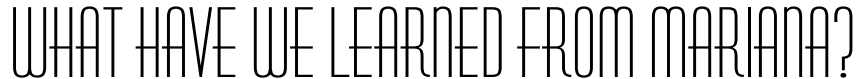

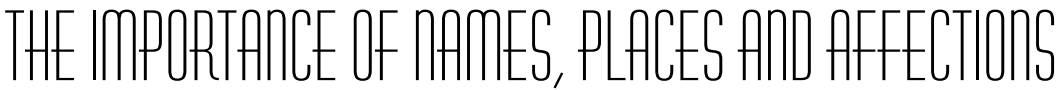

\author{
NADJA ARAÚJO ${ }^{1}$ \\ KEILA CARNAVALLI ${ }^{1}$ \\ LETICIA BARBOSA ${ }^{1}$ \\ NATHALIA SILVA ${ }^{1}$ \\ PATRÍCIA BARCELOS ${ }^{1}$ \\ RAPHAEL SALDANHA ${ }^{1}$ \\ TERESA NEVES ${ }^{1}$ \\ VINICIUS KLEIN ${ }^{1}$ \\ MARIA CRISTINA SOARES GUIMARÃES ${ }^{2}$
}

Naming is an ambitious task. Naming an object or event means recognizing, distinguishing and giving importance to it. Whoever names acquires power over what was previously indescribable. The name is sign and meaning, skewed in origin and use.

Naming and understanding the complexity of what occurred in the city of Mariana and its causes and consequences represents a challenge for which disciplinary approaches centered on scientific knowledge are insufficient. Thus, our search for studies on what happened in Mariana after the failure of the Fundão Dam in November 2015 should be complemented by the stories of residents of that place, by their knowledge. We recognize that this approach to examining such an issue would only be a limited contribution and thus constitutes the primary condition for an interdisciplinary exercise.

When we arrived in Mariana on the night of June 7, 2015, while walking at night in a fair created to guarantee resources for those affected, we realized that their struggle, along with other fronts, signify visibility and voice. The dispute over creating meanings about the tragedy also occurs in the domain of naming. Since 2015, simple people and the residents of districts in the rural area of this municipality have become visible to the world and have appeared in newspapers of several countries to represent what was named the largest ecological tragedy in Brazil. Intense coverage by the media during the first few months after the event was not followed up for nearly three years, when subsequent

1. Doctoral students - Graduate Program in Health Information and Communication, Instituto de Comunicação e Informação Científica e Tecnológica em Saúde (Institute of Communication and Scientific and Technological Information in Health-ICICT-Fiocruz-RJ).

2. Full Professor of the Graduate Program in Health Information and Communication - PPGICS/ICICT/Fiocruz. 
attempts were made to understand the extensive damage, particularly losses suffered by those directly and indirectly affected. During the three days we stayed in Mariana, the struggle to construct meanings regarding what happened and the importance of the words used in this context were ever-present in conversations with these people.

Semiotics is a science that helps us understand the ideological facets of naming (Verón,1980). Crime, tragedy, disaster, crime tragedy, event, accident, impacted ones, stricken ones: every person or group in Mariana has his/her way of naming. People defend and cluster around different names. A certain group that fights to be able to regularly attend the district of Bento Rodrigues to celebrate festive dates, holidays and religious events and for this reason were called crazy, gave meaning to the name “Ones crazy about Bento.” A group of teachers, students and those affected created a newspaper that seeks to provide access to what has occurred since the dam failure and to discuss, among other issues, the previous scenario of action by the responsible mining company, including the lack of a siren that could alert residents at the time of the failure. Not by chance, The Siren is the name of the newspaper. Likewise, the consortium responsible for mining in the region removed the name SAMARCO from the company and created the Renova (Renew) Foundation. This foundation negotiates with the victims and the justice department, promotes events, parties and seminars and will rebuild a new community to settle the residents of Bento Rodrigues and Paracatu de Baixo.

After the dam failure, studies in disaster sociology area such as Zhouri et al. (2016) show that action and repair plans were negotiated, but often without conducting dialogues with affected individuals. Thus, several problems, particularly in the communicational and informational dimension, have affected and still affect the relationship between the mining company and the local communities.

Researchers studying workers' health consider the failure an "extended work accident" because all of Mariana was affected, as a professional in this area of study informed us. The areas of public health and education are widely involved in victim care, either in the reorganization of basic health care for the population, currently distributed throughout the city of Mariana, or in the provision of education for children and adolescents. However, even before the visit, we learned that the school and health center that previously operated in Bento Rodrigues currently accept only former residents of Bento who reside in the city, i.e., Mariana. We are surprised by this news because, analogous to primary health care, municipal schools all over Brazil enroll students from a certain territory composed of nearby neighborhoods. The principal informed us that students were initially welcomed to another school but claimed a space of their own to preserve their ties, which was reinforced by the possibility of resuming their community in a new location in the future. She gave examples of the pedagogical work on the mourning conducted during all this time, which she deems beneficial for children, teachers and families. She also spoke about the large number of donations received at the time of the dam's failure and how, even today, the school forms partnerships to perform school projects because of the great visibility of what happened. However, she knows that this visibility has generated and still generates "jealousy" in Mariana's students, possibly also 
in the principals of other schools. The students and even the former residents of Bento and Paracatu are often called "Mud Feet".

The dam failure not only directly changed the lives of the residents of the six affected communities in the municipality of Mariana but also changed the life of the entire city. The group responsible for mining in the municipality has been unable to operate again, causing a major impact on the region's economy. Some individuals have started to participate in repair actions. Thus, the disputes are occurring not only between the affected individuals and the company but also among the victims who were directly affected by the failure and lost their homes, family, friends, animals and other residents who lost jobs and income.

Considering the spectrum and depth of the consequences of the dam failure on human life, fauna and flora, the adjectives crime, tragic and disastrous all seem appropriate for overcoming dichotomies.

In this struggle over words in Mariana, one also fights for something subtler and more silent. Geography, a science rich in names for discussing "where", can also assist in developing this understanding. Space, territory, landscape, and place are some names-concepts. Where did the tragedy occur? We can interpret space beyond a position on a map to understand the struggle of geographical meanings.

In space, one of the more abstract concepts of geography, the failure is a simple event, occurring at a particular location and time, marked on the map as a record. The tragedy, however, is also territorial, a dispute over who holds dominion over space, who is responsible and to whom that area belongs. We discern a dispute over the domination of the affected areas today: can the residents reoccupy their lands? To whom is it important that the affected areas remain unoccupied? This dispute is territorial.

With respect to the landscape, which is the set of what is observed in terms of the relations of man with his space, everything has changed. In fact, little remains of the landscape in the affected areas because there is no longer a relationship between man and this space. What remains is a trace of what happened. What, however, is the desired future landscape for this area? What relationship between man and his environment is sought? Can this area be reconstructed as a place of memory, so it is not forgotten?

Affected can be synonymous with stricken. Etymologically, though, the word affected derives from the noun affectus, affection. A place can be invested with affection. The dwellers of the stricken areas possess a natural affection for their ancestors' land, for the place where they were born and, until the dam failure, lived. Yi-Fu Tuan (1984) calls this affection "topophilia", the phenomenon of become attached to a place. Because of this attachment, a place is naturally resilient: although the place is destroyed and disfigured as a landscape and redefined as a territory, affection remains and grows fiercer in the face of adversity.

In the tragedy, therefore, there is a clash between territory and place. The geographic space affected by the disaster is a territory for some and a place for others. It is a territory for mineral exploration, economic necessity, employment, development and progress. It requires a guarantee of dominion over space, and its use for this purpose designates it as a priority over other needs. 
Of the needs subjugated by the territorial struggle, one is the necessity for place, to recognize that this space, before becoming a territory, was already a place for families and their ancestors and descendants. Notably, a territory can be mobile, but a place is fixed in space. Affection cannot be moved or artificially transferred to a new location. Topophilia in the case of the affected areas was injured. To regard Nova Bento, for example, as the resettlement of the residents of Bento Rodrigues is to ignore this fact.

Tragedies and adversities can also be life-changing and bring renewal to people and communities. For some affected individuals, the transformation necessitated reestablishing the importance of access to information, mining activity in Brazil and in the world, and legislation on land exploitation and its effects and consequences.

To proceed without looking back, to start anew with family farming, to change businesses, to become a shopkeeper, to want to stay where one have always lived, to want to be paid for what one has lost and to participate in fights for collective causes are some ways of living that the residents of Mariana teach us. There is no right or wrong option, but rather, what is possible in each case.

For some individuals, although the landscape was destroyed, affection for the place remains. The place can be territorialized in the sense that one can fight for its recognition and maintenance, thereby perpetuating the affection for the place, possibly through finding new ways of living.

In this process, the relations between people and place can be constantly renamed and filled with life and affection in both science and common life. This scenario, therefore, presents a valuable opportunity for interdisciplinary research, and seizing this opportunity is the responsibility of science and the academy, of those affected, of each one of us: do not be silent; do not become mute; continue telling this story.

\section{Bibliographic References}

TUAN, Yi-Fu. Topofilia: um estudo da percepção, atitudes e valores do meio ambiente. São Paulo: Difel, 1980.

VERÓN, Eliseo. A produção de sentido. São Paulo: Cultrix, 1980.

ZHOURI, A. et al. O desastre da Samarco e a política das afetações: classificações e ações que produzem o sofrimento social. Cienc. Cult., v. 68, n. 3. 2016.

http://dx.doi.org/10.1590/1809-4422asocnarrativasereflexoesvu2019L1

2019;22:e00002

Narratives and Reflections 